\title{
14. mednarodna IUFRO konferenca o lesnih trohnobah in predstavi- tev evropskega projekta o jesenovem ožigu in holandski brestovi bole- zni (LIFE+ ELMIAS) na Švedskem avgusta 2018
}

\author{
Ana BRGLEZ ${ }^{*}$, Nikica OGRIS ${ }^{1}$
}

Od 26. avgusta do 1. septembra 2018 je v Uppsali in Visbyju na Švedskem potekala že 14. mednarodna IUFRO konferenca na temo trohnobnih gliv (angl. IUFRO WP 7.02.01 "Root \& Stem Rots"). IUFRO (angl. International Union of Forest Research Organizations) je svetovna mreža gozdarskih raziskovalnih organizacij, ki združuje več kot 15.000 raziskovalcev iz 700 članskih organizacij v več kot 110 državah. Cilj tovrstnega povezovanja strokovnjakov je pospeševati raziskovalno odličnost, izmenjavo znanja ter spodbujati razvoj znanstveno zasnovanih rešitev $\mathrm{v}$ korist gozdov in ljudi po vsem svetu (IUFRO, 2018). Organizacija je razdeljena v 9 sekcij. Za Oddelek varstva gozdov na Gozdarskem inštitutu Slovenije je najpomembnejša sekcija št. 7 - Zdravje gozdov (angl. Forest Health), ki se deli na tri podkategorije (1 - Vplivi onesnaževanja zraka in klimatskih sprememb na gozdne ekosisteme, 2 - Fitopatologija, 3 Entomologija).

Fitopatološka sekcija 7.02.01 združuje mednarodno uveljavljene fitopatologe, ki se ukvarjajo s trohnobami korenin in debel gozdnih dreves. Srečanja organizirajo $\mathrm{v}$ intervalih od 3 do 5 let. Tokratno srečanje je gostilo švedsko univerzitetno mesto Uppsala, drugi del pa Visby na otoku Gotland. Konference se je udeležilo okrog 80 raziskovalcev (slika 1). Osrednja tema je bila rdeča trohnoba iglavcev, ki jo povzročajo glive iz rodu Heterobasidion. Predstavljene so bile še raziskave nekaterih drugih aktualnih bolezni in škodljivcev, kot na primer jesenov ožig (Hymenoscyphus fraxineus), holandska brestova bolezen (Ophiostoma ulmi in O. novo-ulmi) in jesenov krasnik (Agrilus planipennis).

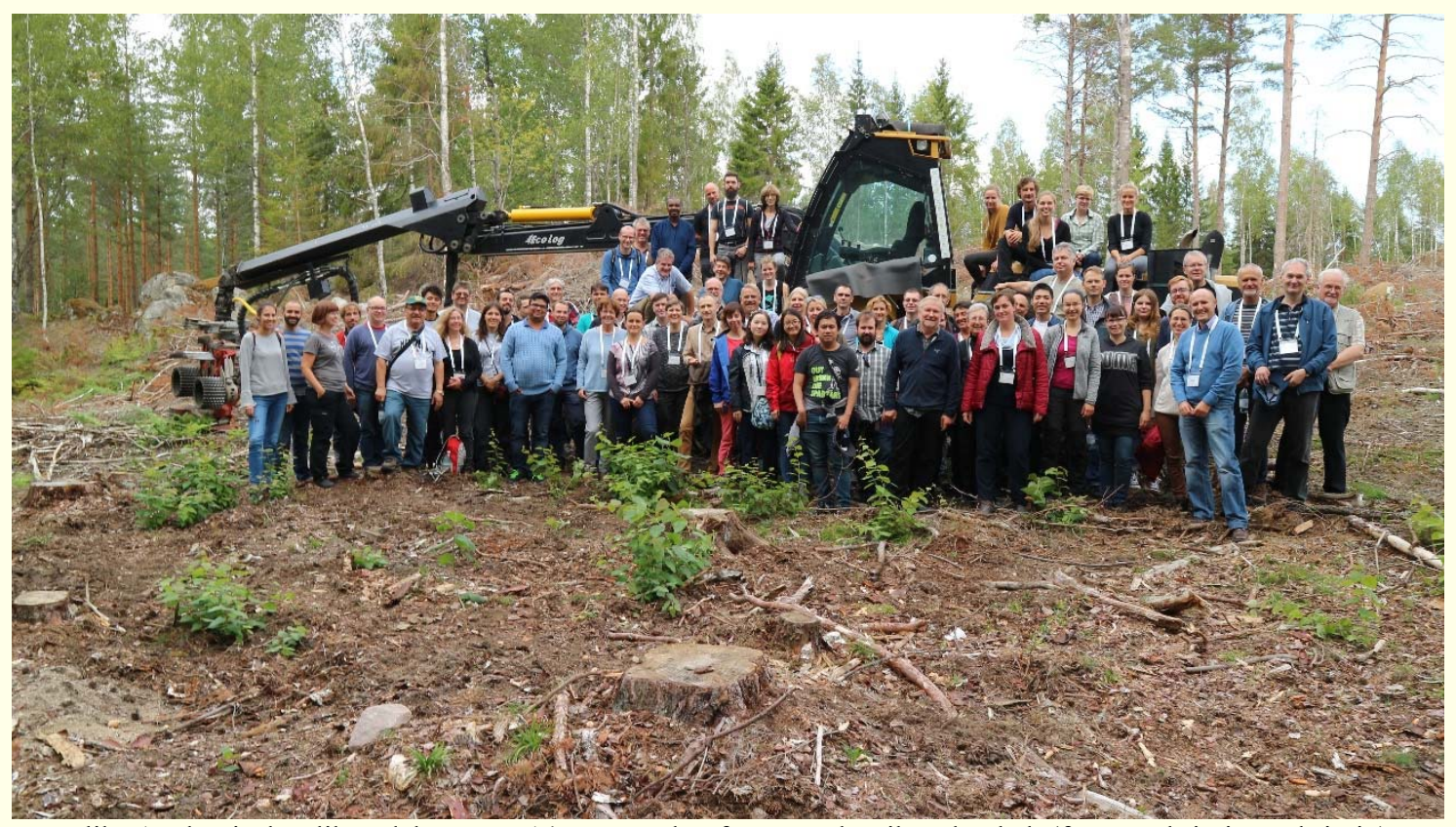

Slika 1: Skupinska slika udeležencev 14. IUFRO konference o lesnih trohnobah (foto: Mukrimin Mukrimin)

Srečanje je bilo sestavljeno iz predstavitev in dveh terenskih dni, kjer smo si udeleženci ogledali tipične težave s katerimi se srečujejo pri gospodarjenju v gozdovih na jugu Švedske. V nadaljevanju povzemamo nekaj glavnih poudarkov srečanja in novosti ter možne prenose znanja in izkušenj. Vsi prispevki so zbrani v knjigi izvlečkov (Vasaitis, 2018).

V prvem delu konference so bila predstavljena predavanja o vrstah, razširjenosti in genetskih raziskavah trohnobnežev (Heterobasidion spp.). Predstavljeni so bili izsledki raziskav iz različnih delov Evrope in Severne Amerike. Znano je, da okužbe s trohnobneži v evropskih gozdovih letno povzročijo približno 800 milijonov $€$ izgub (Woodward in sod., 1998). Rdeče trohnobe so na severu Evrope primarno področje raziskav, saj v njihovem načinu gospodarjenja predstavljajo hud problem. V norveških gozdovih na primer vsako peto drevo pred posekom kaže znake okužbe (Hietala in sod., 2018). Stenlid in sod. (2018) ocenjujejo, da na Švedskem vsak dan zaradi rdeče trohnobe izgubijo 2 milijona $€$. Ekonomske izgube so posledica zmanjšanega prirastka dreves, večje smrtnosti in slabše kakovosti lesa. Znano je, da rdeča trohnoba povzroča večje težave v intenzivno gospodarjenih in spremenjenih gozdovih. Med 
neposrednimi ukrepi proti rdeči trohnobi poznamo premazovanje panjev z ureo ali borati, ki pospešujejo razvoj antagonističnih gliv in premazovanje panjev s suspenzijo oidijev cemprinove nagubanke (Phlebiopsis gigantea (Fr.) Jülich), ki dokazano najbolje zavira rast trohnobnežev. Z omenjenimi pripravki najpogosteje preprečujejo oz. zmanjšujejo okuženost v Skandinaviji in ob Baltiku. Kot dodaten ukrep na Danskem pri jelki v drevesnicah uporabljajo tudi odstranjevanje korenin po poseku (Justesen in Thomsen, 2018). Omenjeni pripravki nimajo dovoljenj za uporabo $\mathrm{v}$ slovenskih gozdovih (Jurc, 2001), odstranjevanje celotnega koreninskega sistema pa bi težko ekonomsko upravičili. Za zatiranje so zato pri nas pomembni predvsem gojitveni ukrepi.

Glede na vsesplošno razširjenost in škode, ki jih povzročajo trohnobneži, bi bilo tudi pri nas smiselno posvetiti več časa raziskovanju omenjenih vrst. Pogled na gozd in gozdarstvo v Sloveniji je sicer precej drugačen kot v golosečno usmerjenih Skandinavskih deželah. Na to kaže drugačen način gospodarjenja, metode in prijemi. Naše ugotovitve o stanju in trendih razvoja lahko najbolje povežemo s srednje evropskimi raziskavami. Sedlak (2018) na Češkem problem rdeče trohnobe povezuje $\mathrm{z}$ načinom gospodarjenja $\mathrm{v}$ preteklosti, ko so nekdanje kmetijske površine obširno pogozdovali s smreko. Posledice teh ravnanj se kažejo v povečanem sanitarnem poseku zaradi biotskih in abiotskih dejavnikov. S klimatskimi spremembami, višjimi temperaturami in pogostejšimi sušami, se bodo okužbe s trohnobneži povečevale. Ker pa se bo količina primernih površin za uspevanje smreke zmanjševala in jo bodo ogrožali številni drugi biotski in abiotski dejavniki, se bo delež smreke $\mathrm{v}$ lesni zalogi nižal in s tem bo upadal tudi pomen trohnobnežev. Tudi naši podatki (Brglez in Ogris, 2018), kažejo trend nižanja količine posekanega lesa zaradi okužb z rdečo trohnobo. Lesna zaloga smreke, kot najbolj občutljive vrste, se namreč v zadnjih letih pri nas vztrajno niža zaradi naravnih ujm in gradacij podlubnikov. Zato skušamo v enomerne gozdove vpeljati vedno več rastiščm primernih listavcev. Izgube zaradi rdeče trohnobe v mešanih sestojih so namreč nižje kot v smrekovih monokulturah (Piri in sod., 1990; Linden in Vollbrecht, 2002). Mešani gozdovi so tudi stabilnejši in bolj vzdržljivi ob ostalih biotskih in abiotskih motnjah.

$\mathrm{Na}$ srečanju je bilo predstavljenih tudi veliko raziskav s področja molekularnih analiz, možnosti za povečanje odpornosti gostiteljskih vrst proti rdeči trohnobi z žlahtnjenjem, prenosa odpornosti na potomstvo ipd. Tudi na prvem terenskem dnevu smo spoznavali probleme in rešitve povezane $\mathrm{z}$ rdečo trohnobo $\mathrm{v}$ smrekovih plantažah. Na Švedskem vsako leto vzgojijo 200 milijonov sadik smreke, ki jih večinoma posadijo v plantaže. Tu pa se kasneje pojavijo težave s trohnobneži. Zato poskušajo z raziskavami najti odporne osebke, ki bi jih kasneje vegetativno razmnoževali. V nadaljevanju smo si ogledali še delo stroja za sečnjo v prvem redčenju sestoja, ki je imel na procesorski glavi poseben sistem za aplikacijo antagonistične glive cemprinove nagubanke na panje takoj ob poseku (pripravek Rotstop ${ }^{\circledR}$ in barvilo) (slika 2). Tretiranje izvajajo pri temperaturah višjih od $5{ }^{\circ} \mathrm{C}$ na vseh panjih smreke in po želji lastnika tudi na boru.

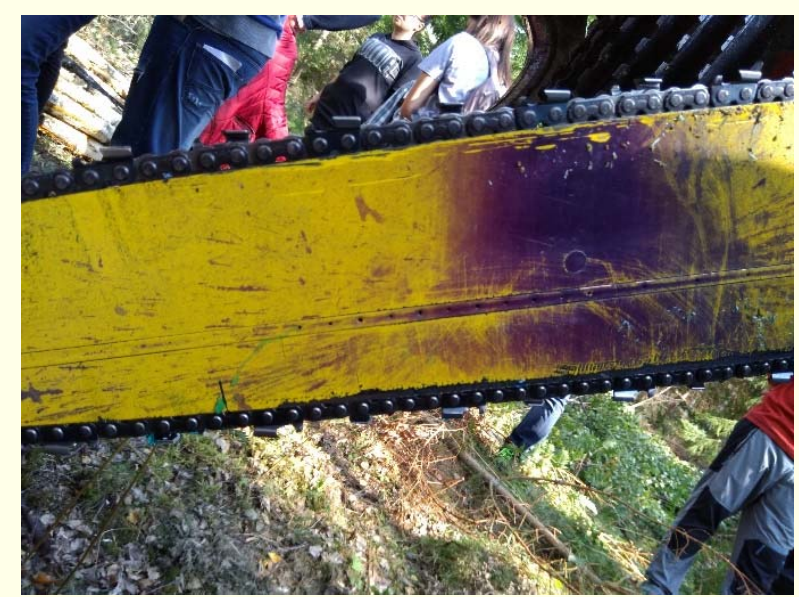

Slika 2: Procesorska glava harvesterja s prilagojenim mečem (luknjice, ki dovajajo pripravek Rotstop ${ }^{\circledR}$ in barvilo) (foto: Ana Brglez)

Drugi del konference je bil namenjen predstavitvi stanja in trendov jesenovega ožiga (Hymenoscyphus fraxineus) in holandske brestove bolezni (Ophiostoma ulmi in Ophiostoma novo-ulmi). Poudarek je bil na prognozah za prihodnost. Na otoku Gotland so namreč v letu 2005 odkrili holandsko brestovo bolezen. Za njen prenos je tam odgovoren mali brestov beljavar (Scolytus multistriatus), ki hitro širi bolezen po otoku. Vsako leto povzroči propad okoli 5.000 brestov (Menkis in sod., 2018a). Projekt LIFE+ ELMIAS financira zatiralne ukrepe proti bolezni, ki po ocenah letno stanejo okoli 0,5 milijona $€$. Ukrepi vključujejo iskanje okuženih dreves, posek in pogozditev ter informiranje javnosti za omejevanje širjenja in novih vnosov bolezni. Po ocenah je na Gotlandu na ta način preživelo $90 \%$ brestov. Na otoku Öland, kjer ne izvajajo ukrepov izkoreninjanja in omejevanja širjenja, pa le 5-10\%. Zaradi pomembne biotopske vrednosti bresta se jim zdi smiselno boriti proti bolezni, vendar se sprašujejo kako zagotoviti potrebna sredstva po poteku projekta (Wågström in Oleskog, 2018). Ocene stanja brestov v Sloveniji kažejo, da poškodbe zaradi holandske brestove bolezni stagnirajo in da se stanje v določenih pogledih celo malenkostno izboljšuje. Jih pa dodatno ogrožajo drugi škodljivi dejavniki, na primer naravne ujme (Ogris, 2018).

Dodatno težavo na otoku Gotland predstavlja tudi močno razširjena gliva Hymenoscyphus fraxineus, ki povzroča jesenov ožig. Na konferenci je bila predstavljena akcija za poskus ohranitve velikega jesena (Fraxinus excelsior L.), kot edinega predstavnika jesenov na Švedskem. Menkis in sod. (2018b) so kartirali zdrave oz. nesimptomatične osebke jesenov in na poskusnem polju sejali njihovo seme. Poleg tega so posadili tudi 2-3 letne asimptomatične sadike, ki so jih našli v gozdu. Po dveh letih ugotavljajo, da je preživelo $60 \%$ jesenov, ki ne kažejo simptomov jesenovega ožiga. Tudi monitoring "starševskih" dreves je pokazal, da so še vedno brez simptomov bolezni. S poskusom poskušajo ustvariti zbirko z najmanj 100 domnevno odpornimi genotipi velikega jesena z Gotlanda, ki bi jih lahko v prihodnje razmnoževali in uporabljali za sadnjo. Zavedajo se, da je takšen način iskanja odpornosti precej nestrokoven in da bo deloval samo v primeru, da v Evropo ne bo vnesen nov, morda bolj patogen sev glive povzroči- 
teljice jesenovega ožiga. V Evropi jesenov ožig povzroča alarmantno odmiranje jesena in izpodriva neagresivno avtohtono glivo Hymenoscyphus albidus (McMullan in sod., 2018). Prognoze za Slovenijo se ne razlikujejo dosti od ugotovitev ostalih raziskovalcev. Ogris (2018) namreč napoveduje eksponentno večanje sanitarne sečnje jesena (4-10\% lesne zaloge na leto) in 20$40 \%$ znižanje lesne zaloge jesena v obdobju desetih let.

Zadnji dan smo si na terenu ogledali z Naturo 2000 zavarovana travišča (slika 3), ki jih vzdržujejo na tradicionalen način. Značilna je mozaična zgradba krajine, v kateri prevladujejo jesen, brest in hrast. Tu smo spoznali način gospodarjenja $\mathrm{v}$ povezavi $\mathrm{z}$ jesenovim ožigom in holandsko brestovo boleznijo. Pri jesenu poskušajo ohranjati asimptomatične osebke ter spodbujati in varovati njihovo naravno nasemenitev. Pri brestu pa novo

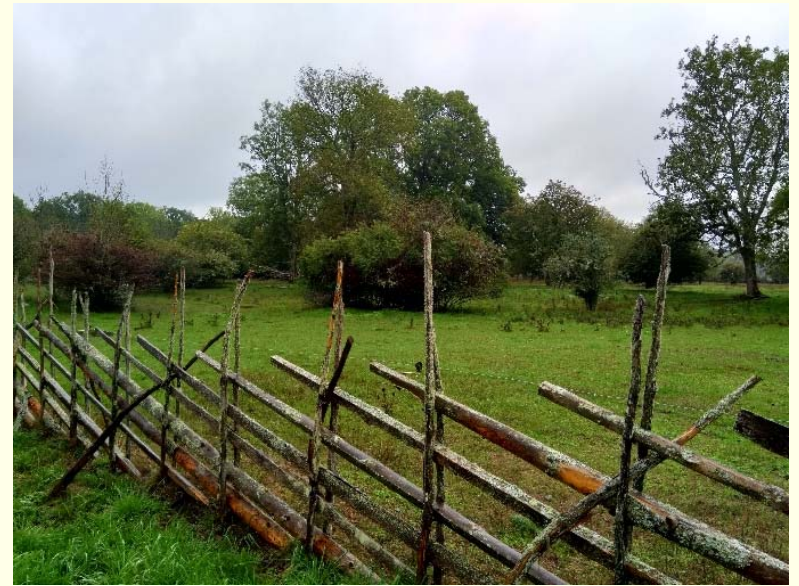

Slika 3: Tradicionalen krajinski tip (travišče) na otoku Gotland (foto: Ana Brglez)

\section{Viri}

Brglez A., Ogris N. 2018. Situation of Armillaria spp. and Heterobasidion spp. in Slovenia. V: Proceedings of International LIFE+ ELMIAS Ash and Elm, and IUFRO WP 7.02.01 Root and Stem Rots Conference (LIFE-IUFRO), 26.8. - 1.9.2018. Vasaitis R. (ur.). Uppsala in Visby, Sweden, Swedish University of Agricultural Sciences, Uppsala: 86.

Hietala A.M., Solheim H., Hanssen K., Talbot B., Astrup R. 2018. Precision forestry for improved resource utilization and reduced wood decay in Norwegian forests. V: Proceedings of International LIFE+ ELMIAS Ash and Elm, and IUFRO WP 7.02.01 Root and Stem Rots Conference (LIFE-IUFRO), 26.8. - 1.9.2018. Vasaitis R. (ur.). Uppsala in Visby, Sweden, Swedish University of Agricultural Sciences, Uppsala: 16.

Jurc D. 2001. Rdeča trohnoba. Povzročitelji, opis bolezni in ukrepi proti njej. Ljubljana, Gozdarski inštitut Slovenije: 36 str.

Justesen M.J., Thomsen I.M. 2018. Heterobasidion annosum root rot in noble fir combined with bark beetle attack. V: Proceedings of International LIFE+ ELMIAS Ash and Elm, and IUFRO WP 7.02.01 Root and Stem Rots Conference (LIFE-IUFRO), 26.8 - 1.9.2018. Vasaitis R. (ur.). Uppsala and Visby, Sweden, Swedish University of Agricultural Sciences, Uppsala: 22.

Linden M., Vollbrecht G. 2002. Sensitivity of Picea abies to Butt Rot in Pure Stands and in Mixed Stands with Pinus sylvestris in Southern Sweden. Silva Fennica, 36, 4: 767-778

McMullan M., Rafiqi M., Kaithakottil G., Clavijo B.J., Bilham L., Orton E., Percival-Alwyn L., Ward B.J., Edwards A., Saunders D.G.O., Garcia Accinelli G., Wright J., Verweij W., Koutsovoulos G., Yoshida K., Hosoya T., Williamson L.Ž., Jennings P., Ioos R., Husson C., Hietala A.M., Vivian-Smith A., Solheim H., MaClean D., Fosker C., Hall N., K. M. Brown J., Swarbreck D., Blaxter M., Downie J.A., D. Clark M. 2018. The ash dieback invasion of Europe was founded by two genetically divergent individuals. Nature Ecology and Evolution, 2: 1000-1008 okužena drevesa čimprej posekajo in glivi preprečijo okužbe panjevskih odganjkov z vstavljanjem plastičnih ampul s herbicidom na osnovi glifosata med skorjo in les, ki ubijejo panj (slika 4) (Menkis in sod., 2016). Menkis in sod. (2017) so testirali tudi alternativno metodo, kjer so širjenje glive preprečevali z nanosom dveh vrst trohnobnih gliv (Chondrostereum purpureum in Stereum hirsutum) na sveže panje. Ta način se je izkazal za skoraj povsem neučinkovitega pri uničevanju panjev bresta in kontrolo širjenja bolezni skozi koreninski sistem. Ohranitev omenjenih drevesnih vrst je sicer nujna za ohranjanje tradicionalnega tipa travišč, ki predstavljajo pomembno kulturno in naravno dediščino Švedske in celotne Evrope.

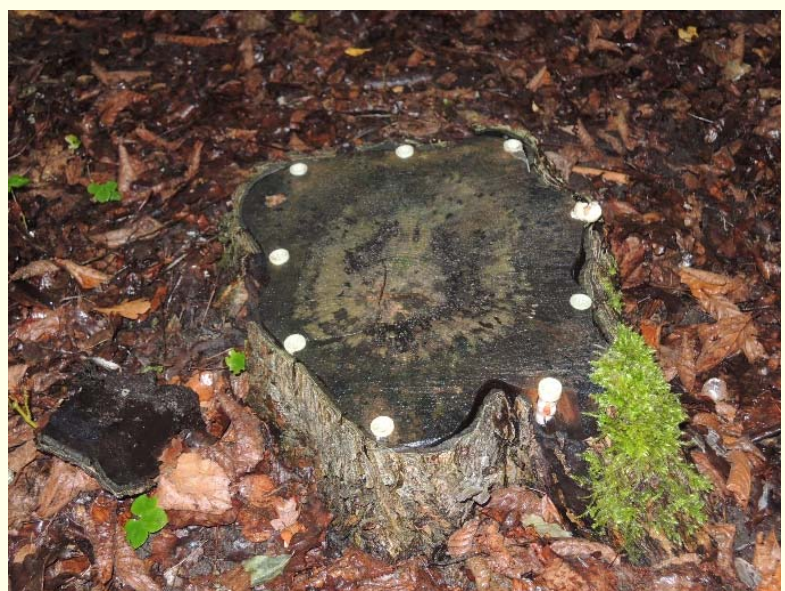

Slika 4: Brestov panj z ampulami glifosata med skorjo in lesom (foto: Nikica Ogris)

Menkis A., Davydenko K., Wågström K., Östbrant I.L., Stenlid J., Vasaitis R. 2018a. Scolytus multistriatus on Gotland Island: phenology and infectiousness with Dutch Elm Disease. V: Proceedings of International LIFE+ ELMIAS Ash and Elm, and IUFRO WP 7.02.01 Root and Stem Rots Conference (LIFE-IUFRO), 26.8. - 1.9.2018. Vasaitis R. (ur.). Uppsala and Visby, Sweden, Swedish University of Agricultural Sciences, Uppsala: 48.

Menkis A., Davydenko K., Zaluma A., Stenlid J., Vasaitis R. 2018b. Testing ash for resistance to dieback: an amateurish approach. V: Proceedings of International LIFE+ ELMIAS Ash and Elm, and IUFRO WP 7.02.01 Root and Stem Rots Conference (LIFE-IUFRO), 26.8. - 1.9.2018. Vasaitis R. (ur.). Uppsala and Visby, Sweden, Swedish University of Agricultural Sciences, Uppsala: 74.

Menkis A., Östbrant I.L., Wågström K., Vasaitis R. 2016. Dutch elm disease on the island of Gotland: monitoring disease vector and combat measures. Scandinavian Journal of Forest Research, 31, 3: 1-5

Menkis A., Vasaitis R., Östbrant I.L., Pliūra A., Stenlid J. 2017. Tests with Wood-Decay Fungi to Control Sprouting from Cut Stumps Infected by Dutch Elm Disease. Baltic Forestry, 23, 1: 270-273

Ogris N. 2018. Ash DieBack and Dutch Elm Disease: current situation and prospects in Slovenia. V: Proceedings of International LIFE+ ELMIAS Ash and Elm, and IUFRO WP 7.02.01 Root and Stem Rots Conference (LIFE-IUFRO), 26.8. - 1.9.2018. Vasaitis R. (ur.). Uppsala and Visby, Sweden, Swedish University of Agricultural Sciences, Uppsala: 104.

Piri T., Korhonen K., Sairanen A. 1990. Occurrence of Heterobasidion annosum in pure and mixed spruce stands in Southern Finland. Scandinavian Journal of Forest Research, 5, 1-4: 113-125

Sedlak P. 2018. Quo vadis, Heterobasidion? V: Proceedings of International LIFE+ ELMIAS Ash and Elm, and IUFRO WP 7.02.01 Root and Stem Rots Conference (LIFE-IUFRO), 26.8. - 1.9.2018. Vasaitis R. (ur.). Uppsala and Visby, Sweden, Swedish University of Agricultural Sciences, Uppsala: 17.

Stenlid J., Menkis A., Vasaitis R., Wågström K. 2018. Fighting Dutch Elm Disease on the Gotland Island. What have we leant and what can we expect for the future? V: Proceedings of International LIFE+ 
ELMIAS Ash and Elm, and IUFRO WP 7.02.01 Root and Stem Rots Conference (LIFE-IUFRO), 26.8. - 1.9.2018. Vasaitis R. (ur.). Uppsala and Visby, Sweden, Swedish University of Agricultural Sciences, Uppsala: 64.

Vasaitis R. 2018. Proceedings of International LIFE+ ELMIAS Ash and Elm, and IUFRO WP 7.02.01 Root and Stem Rots Conference (LIFE-IUFRO), 26.8. - 1.9.2018, Uppsala in Visby, Sweden, Swedish University of Agricultural Sciences, Uppsala: 112.

Wågström K., Oleskog G. 2018. ELMIAS: LIFE + project on managing wooded meadows of Gotland under the threat of Dutch Elm Disease and Ash Die-Back. V: Proceedings of International LIFE+ ELMIAS Ash and Elm, and IUFRO WP 7.02.01 Root and Stem Rots
Conference (LIFE-IUFRO), 26.8. - 1.9.2018. Vasaitis R. (ur.). Uppsala and Visby, Sweden, Swedish University of Agricultural Sciences, Uppsala: 63.

Woodward S., Stenlid J., Karjalainen R., Hüttermann A. 1998. Heterobasidion annosum: biology, ecology, impact and control. Wallingford, UK, CAB International: 589 str.

${ }^{1}$ Gozdarski inštitut Slovenije, Večna pot 2, 1000 Ljubljana *ana.brglez@gozdis.si 